\title{
Prolyl 4-Hydroxylase Subunit Alpha-2
}

National Cancer Institute

\section{Source}

National Cancer Institute. Prolyl 4-Hydroxylase Subunit Alpha-2. NCI Thesaurus. Code C101551.

Prolyl 4-hydroxylase subunit alpha-2 (535 aa, $62 \mathrm{kDa}$ ) is encoded by the human P4HA2 gene. This protein is involved in collagen maturation. 